\title{
Edukasi Pencegahan Hipertensi Menuju Lansia Sehat Di Dusun Tegaltandan, Desa Banguntapan, Bantul
}

\author{
Liena Sofiana*1, Nindy Fadellah Wulan Safitri², Rizka Yuli Mulyani ${ }^{3}$, Ibnu Muslih4 \\ 1,2,3,4Fakultas Kesehatan Masyarakat, Universitas Ahmad Dahlan Yogyakarta \\ *e-mail: liena.sofiana@ikm.uad.ac.id
}

\begin{abstract}
Hypertension is still one of the health problems in Indonesia with a high blood pressure population prevalence of $34.11 \%$. Based on data from the Yogyakarta City Health Office in 2018 hypertension cases were found as many as 18,945 cases. In the Health Profile of Banguntapan III Health Center in 2016, hypertension was number 1 of the top 10 diseases based on visits to the Banguntapan III Health Center. The increase in this case can be caused by several factors, namely the lack of knowledge, attitudes that people have about hypertension so that people have a low behavior to make efforts to prevent hypertension. Health education about hypertension with counseling methods and poster media is one way to increase knowledge. The purpose of this activity is to find out the description of knowledge about hypertension through counseling at the Elderly Posyandu of Tegaltandan. The method used is interactive counseling for the elderly in Tegaltandan directly with poster media. The results obtained were health counseling activities at the Posyandu Elderly running well and smoothly, participants actively gave questions and followed the activities from start to finish conducive.
\end{abstract}

Keywords: Health education, hypertension, knowledge.

\begin{abstract}
Abstrak
Hipertensi masih menjadi salah satu masalah kesehatan di Indonesia dengan prevalensi penduduk tekanan darah tinggi sebesar 34,11\%. Berdasarkan data Dinas Kesehatan Kota Yogyakarta pada tahun 2018 kasus hipertensi ditemukan sebanyak 18.945 kasus. Dalam Profil Kesehatan Puskesmas Banguntapan III tahun 2016, hipertensi menjadi nomor 1 dari 10 besar penyakit berdasarkan kunjungan di Puskesmas Banguntapan III. Peningkatan kasus ini dapat disebabkan oleh beberapa faktor yaitu kurangnya pengetahuan, sikap yang dimiliki masyarakat mengenai hipertensi sehingga masyarakat memiliki perilaku yang rendah untuk melakukan upaya pencegahan hipertensi. Pendidikan kesehatan tentang hipertensi dengan metode penyuluhan dan media poster menjadi salah satu cara untuk meningkatan pengetahuan. Tujuan kegiatan ini untuk mengetahui gambaran pengetahuan mengenai hipertensi melalui konseling di Posyandu Lansia Dusun Tegaltandan. Metode yang digunkan yaitu konseling interaktif pada lansia di Dusun Tegaltandan secara langsung dengan media poster. Hasil yang diperoleh adalah kegiatan konseling kesehatan di Posyandu Lansia berjalan dengan baik dan lancar, peserta turut aktif memberi pertanyaan dan mengikuti kegiatan dari awal sampai selesai dengan kondusif.
\end{abstract}

Kata kunci: Edukasi kesehatan, hipertensi, pengetahuan

\section{PENDAHULUAN}

Hipertensi atau biasa disebut dengan silent killer merupakan penyakit yang datang tanpa disertai timbulnya gejala. Penyakit hipertensi akan mengganggu system peredaran darah berdampak pada meningkatkan tekanan darah di atas normal sehingga berisiko memunculkan komplikasi seperti penyakit jantung, gagal ginjal dan stroke (WHO, 2011). Hipertensi menjadi salah satu penyakit penyebab utama kematian di dunia. Berdasarkan estimasi World Health Organization (WHO) menunjukkan prevalensi hipertensi sebesar $22 \%$ dari total penduduk dunia. Kurang dari seperlima dari total prevalensi tersebut melakukan upaya pengendalian terhadap tekanan darahnya. Prevalensi hipertensi tertinggi berasa di wilayah Afrika sebesar 27\%, sedangkan Asia Tenggara berada di posisi ke tiga sebesar 25\% terhadap total penduduk (World Health Organization, 2019).

Hasil Riset Kesehatan Dasar (Riskesdas) berdasarkan pengukuran tahun 2018 menunjukkan angka prevalensi hipertensi secara nasional meningkat menjadi $34,11 \%$ pada penduduk usia > 18 tahun daripada tahun 2013 sebesar 25,8\%. Prevalensi hipertensi tertinggi 
tahun 2018 berada di Kalimantan Selatan sebesar 44,13\%, Jawa Barat sebesar 39,6\% dan Kalimantan Timur sebesar 39,3\% (Kementerian Kesehatan RI, 2019).

Proporsi hipertensi berdasarkan pengukuran menunjukkan bahwa kelompok perempuan memiliki proporsi lebih besar dibandingkan laki-laki. Pola tersebut terjadi pada tahun 2013 dan 2018. Kelompok umur juga mempengaruhi proporsi hipertensi. Proporsi meningkat seiring peningkatan umur. Secara fisiologis, semakin tinggi umur seseorang maka semakin berisiko untuk terkena hipertensi. Proporsi hipertensi tertinggi terjadi pada kelompok umur $\geq 75$ tahun sebesar 63,8\% pada tahun 2013 dan meningkat menjadi 69,5\% pada tahun 2018 (Kementerian Kesehatan RI, 2019).

Kelompok lansia ditinjau dari aspek kesehatan akan mengalami penurunan derajat kesehatan. Angka kesakitan penduduk lansia sejak tahun 2005 hingga 2014 fluktuatif. Angka kesakitan tertinggi terjadi pada tahun 2009 yaitu sebesar 30,46\% yang artinya dari setiap 100 orang lansia terdapat 30 orang diantaranya sakit. Lansia rentan terkena penyakit degenerative dikarenakan penurunan daya tahan tubuh dan proses menghilangnya kemampuan jaringan untuk memperbaiki kerusakan yang diderita seperti diabetes melitus, gagal ginjal, kanker dan hipertensi (Kementerian Kesehatan RI, 2016).

Penelitian yang dilakukan oleh Mujiran dkk (2019) menunjukkan bahwa penderita hipertensi didominasi oleh perempuan yaitu sebanyak 58,2\%. Hal tersebut dikarenakan usia harapan hidup perempuan lebih tinggi daripada laki-laki. Hal tersebut berlawanan dengan penelitian yang dilakukan oleh Zaenurrohmah (2017) bahwa jenis kelamin berkaitan dengan jumlah kunjungan lansia. Data pendahuluan tentang kejadian hipertensi tidak membedakan jenis kelamin. Setiap orang laki-laki dan perempuan memiliki risiko terkena hipertensi (Centers for Disease Control and Prevention, 2014).

Edukasi atau pendidikan merupakan segala upaya yang direncanakan untuk mempengaruhi orang lain baik individu, kelompok, atau masyarakat sehingga mereka melakukan apa yang diharapkan oleh pelaku pendidikan (Notoatmodjo, 2010). Penyuluhan merupakan salah satu cara yang dapatdilakukan untuk menambah pengetahuan/informasibagi masyarakat. Penyuluhan dengan bertatap mukadan memberikan informasi secara langsung diharapkan dapat lebih efektif dibandingkan dengan tindakan penyuluhan melalui media massa atau pun selebaran (Wowiling et al., 2013). Pendekatan edukasi dengan promosi kesehatan merupakan salah satu cara terbaikuntuk memberikaninformasi dan motivasi yang dapat dipercaya padamasyarakat dan membantu individu mengembangkan kemampuan membuatkeputusan dan memberikan pencitraan pada masyarakat untuk menggali danmengembangkan sikap dan tindakan yang semestinya (Darmawan \& Zulfa, 2013).

Tujuan dari pendidikan kesehatan menurut Undang-Undang Kesehatan No. 23 tahun 1992 yaitu meningkatkan kemampuan masyarakat untuk memelihara dan meningkatkan derajat kesehatan baik fisik, mental, dan sosialnya sehingga produktif secara ekonomi maupun secara sosial, pendidikan kesehatan disemua program kesehatan baik pemberantasan penyakit menular, sanitasi lingkungan, gizi masyarakat pelayanan kesehatan maupun program kesehatan lainnya (Undang-Undang Kesehatan No. 23, n.d.).

Menurut Purwanti, Bidjuni dan Babakal dalam Sofiana, Puratmadja, Kartika, Pangulu dan Putri (2018) menyebutkan bahwa penyuluhan kesehatan berpengaruh terhadap peningkatan pengetahuan perilaku klien hipertensi, akan meningkatkan pola hidup sehingga dapat mengontrol tekanan darah dengan baik. Berdasarkan data tersebut maka sangat baik apabila adanya kegiatan penyuluhan kesehatan mengenai hipertensi pada lansia dengan bantuan media poster di Dusun Tegaltandan Banguntapan Bantul Yogyakarta (Sofiana et al., 2018).

\section{METODE}

Metode yang digunakan dalam kegiatan edukasi ini adalah konseling secara langsung dan juga didukung oleh media poster yang berisi faktor risiko hipertensi, gejala hipertensi, komplikasi, 
cara mencegah dan cara mengendalikan hipertensi. Selain itu juga dilakukan pemeriksaan tekanan darah yang dilanjutkan dengan tanya jawab antara pemateri dengan lansia yang ada di posyandu. Pemateri terdiri dari 4 orang yaitu berasal dari Fakultas Kesehatan Masyarakat Universitas Ahmad Dahlan. Kegiatan ini dilakukan intervensi ini dapat berjalan dengan baik karena bekerja sama dengan posyandu lansia di Dusun Tegaltandan dan Puskesmas Banguntapan III yang menjadi fasilitator.

\section{HASIL DAN PEMBAHASAN}

Kegiatan intervensi ini dilaksanakan pada hari selasa tanggal 25 Februari 2020. Peserta kegiatan terdiri dari lansia baik laki-laki maupun perempuan yang datang ke Posyandu Lansia di Dusun Tegaltandan berjumlah 18 lansia. Kegiatan intervensi ini berupa pemeriksaan tekanan darah pada lansia. Berdasarkan kegiatan pemeriksaan tekanan darah pada lansia di Dusun Tegaltandan terdapat 9 lansia yang mengalami hipertensi. Gambaran jumlah lansia yang mengalami hipertensi tersaji pada gambar 1.

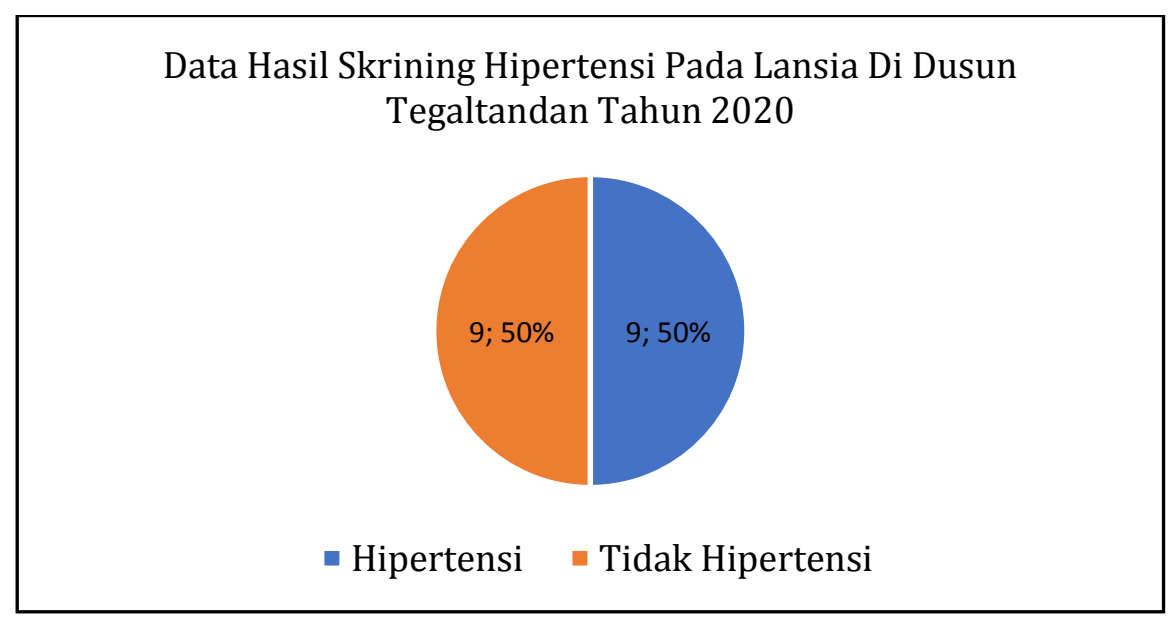

Gambar 1. Hasil Pengukuran Tekanan Darah pada Lansia

Selain pengukuran tekanan darah, dalam kegiatan pengabdian ini juga dilakukan konseling kesehatan tentang hipertensi melalui media poster yang digunakan sebagai media promosi kesehatannya. Kemudian para peserta diperkenankan untuk memberikan pertanyaan terkait dengan hipertensi kepada pemateri. Tidak hanya memberikan materi saja, tetapi lansia juga diberikan leaflet untuk dibawa pulang sebagai bahan bacaan jika terlupa. Selain itu, kegiatan intervensi ini juga memberian buah-buahan yang dapat menurunkan tekanan darah seperti buah semangka sebagai salah satu cara alami untuk menurunkan tekanan darah tanpa harus mengkonsumsi obat-obatan. Pelaksanaan kegiatan intervensi dapat dilihat pada Gambar 1 dan 2.

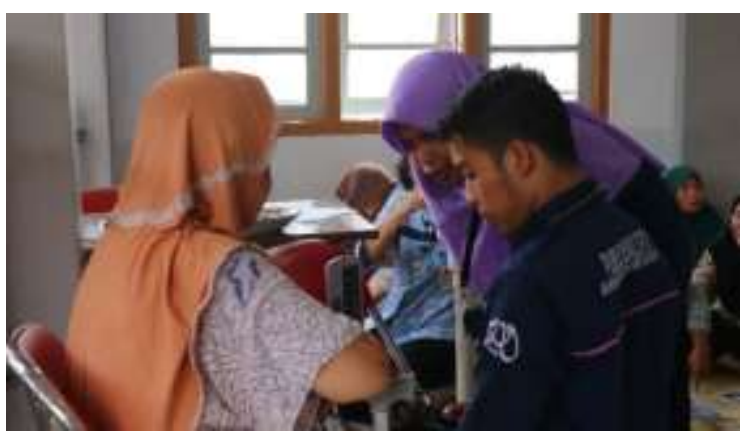

Gambar 2. Pemeriksaan tekanan darah

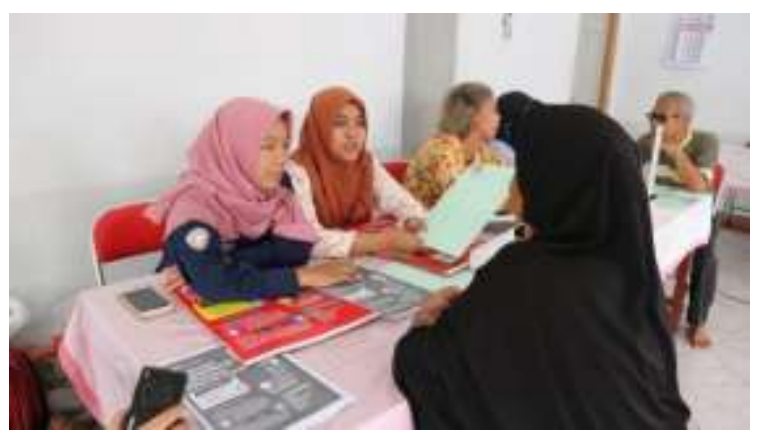

Gambar 3. Pelaksanaan kegiatan konseling hipertensi pada lansia 
Metode konseling tentang hipertensi seperti faktor risiko, gejala, komplikasi, cara mencegah dan cara mengendalikan hipertensi merupakan salah satu bentuk dari promosi kesehatan. Kegiatan konseling ini bertujuan untuk memberikan pengetahuan terkait hipertensi kepada lansia agar lansia dapat melakukan upaya pencegahan dan pengendalian penyakit hipertensi. Pendidikan kesehatan merupakan prioritas utama dan merupakan salah satu intervensi yang efektif untuk meningkatkan tingkat kesadaran masyarakat akan pentingnya pemahaman yang benar mengenai hipertensi. Hubungan antara tingkat pendidikan dengan hipertensi bisa dikatakan hubungan tidak langsung. Hal ini karena adanya peran pengetahuan, dimana tingkat pendidikan akan mempengaruhi pengetahuan seseorang, pengetahuan yang baik kemudian akan menimbulkan kesadaran seseorang. Kesadaran masyarakat tentang faktor Risiko hipertensi akan membuat mereka dengan sadar merubah gaya hidupnya (Amu, 2015). Hal ini sejalan dengan penelitian yang dilakukan oleh Eva Sartika (2017) bahwa pengetahuan yang baik dapat mempengaruhi kepatuhan seseorang terhadap diit garam dan pengontrolan tekanan darah (Sartika, 2017). Demikian juga hasil penelitian Kusnanto (2018) yang menyatakan tingkat pengetahuan berpengaruh terhadap self management pada pasien penderita diabetes mellitus (Kusnanto, 2019).

Pendidikan kesehatan merupakan bentuk intervensi terutama pada faktor perilaku. (Notoatmodjo, 2012). Notoatmodjo (2012) juga mengemukakan Promosi kesehatan dalam arti pendidikan, secara umum adalah segala upaya yang direncanakan untuk mempengaruhi orang lain, baik individu, kelompok, atau masyarakat, sehingga mereka melakukan apa yang diharapkan oleh pelaku pendidikan atau promosi kesehatan. pendidikan yang dimaksud adalah pendidikan kesehatan, yaitu segala upaya yang direncanakan untuk mempengaruhi orang lain, baik individu, kelompok, atau masyarakat, sehingga mereka melakukan apa yang diharapkan oleh pelaku pendidikan atau promosi kesehatan. Daribatasan ini tersirat unsur-unsur input (sasaran dan pendidik dari pendidikan), proses (upaya yang direncanakan untuk mempengaruhi orang lain) dan output (melakukan apa yang diharapkan) (Notoatmodjo, 2012).

Penelitian Bakhtiar (2012) juga menunjukkan pengetahuan merupakan hasil dari usaha dalam mencari tau pengalaman yang diperoleh sesorang selama hidup juga dapat menjadikan pengetahuan (Bakhtiar, 2012). Hal ini sesuai dengan penelitian Machfordz (2010) bahwa ilmu pengetahuan adalah kumpulan dari pengalaman-pengalaman seseorang sehingga responden memiliki nilai baik, selain itu dukungan teman juga menjadi pengaruh kualitas hidup responden (Machfoedz, 2010). hal ini sesuai dengan penelitian Azmi (2018) bahwa kualitas hidup seseorang akan baik karena memperoleh dukungan dari teman dan lingkungan sosialnya (Azmi, 2018).

Penelitian Sumartono dan Astuti (2018) menyebutkan bahwa poster banyak diminati oleh sebagian orang karena gambar jelas dengan warna yang cerah, penggunaan kata dan kalimat yang singkat dan sederhana, serta bahasa yang digunakan mudah dipahami sehingga apa yang ingin disampaikan oleh pemateri dapat tersampaikan kepada pembacanya. Pemahaman yang lebih mendalam diperoleh jika poster tidak hanya menjadi pajangan begitu saja, tetapi harus diulang secara lisan baik dari petugas kesehatan, penyuluh, dan lain-lain (Sumartono \& Astuti, 2018).

Penelitian Harsismanto, Oktavidianti, dan Astuti (2019) yang berjudul "Pengaruh Pendidikan Kesehatan Media Video dan Poster Terhadap Pengetahuan dan Sikap Anak dalam Pencegahan Diare" menunjukkan bahwa pendidikan kesehatan dengan media poster meningkatkan pengetahuan anak dalam melakukan pencegahan penyakit diare (Harsismanto et al., 2019). Notoatmojo (2010) menyebutkan faktor-faktor yang mempengaruhi pengetahuan yaitu pendidikan, media massa/ infomasi, sosial budaya dan ekonomi, seta lingkungan dan pengalaman (Notoatmodjo, 2010).

\section{KESIMPULAN}

Pelaksanaan kegiatan konseling kepada lansia di Posyandu Lansia Dusun Tegaltandan Banguntapan Bantul dapat terlaksana dengan baik dan lacar dan juga kondusif. Lansia aktif 
memberi pertanyaan dan antusias serta beberapa dari mereka bahkan bercerita kehidupan sehari-harinya. Kegiatan konseling ini diharapkan lansia memiliki pengetahuan yang baik mengenai hipertensi dan dapat melakukan upaya pencegahan dan pengendaliannya.

\section{UCAPAN TERIMAKASIH}

Terima kasih diucapkan kepada:

a. Universitas Ahmad Dahlan sebagai Institusi yang memberikan dukungan sehingga kegiatan intervensi ini dapat berjalan dengan baik.

b. Pemerintah Desa Banguntapan Bantul Yogyakarta yang telah memberikan dukungan dan bantuan selama proses pelaksanaan kegiatan intervensi

c. Dusun Tegaltandan dan ibu-ibu kader yang telah mendukung dan berperan aktif dalam pelaksaan intervensi dari awal hingga akhir kegiatan.

\section{DAFTAR PUSTAKA}

Amu, D. A. (2015). Hipertensi di Wilayah Perkotaan dan Pedesaan di Indonesia.

Azmi, N. (2018). Gambaran Kualitas Hidup Lansia Dengan Hipertensi Di Wilayah Kerja Puskesmas Sidomulyo Kecamatan Tampan Pekanbaru. JOM FKP, 5(2), 1-10.

Bakhtiar, A. (2012). Filsafat Ilmu. PT Raja Grafindo Persada.

Centers for Disease Control and Prevention. (2014). High Blood Pressure.

Darmawan, D., \& Zulfa, S. (2013). Pengaruh Promosi Kesehatan terhadap Motivasi Pasien Hipertensi Tentang Pelaksanaan Diet Hipertensi di Poli Klinik Penyakit Dalam RS. Rajawali Bandung.

Harsismanto, J., Oktavidiati, E., \& Astuti, D. (2019). Pengaruh Pendidikan Kesehatan Media Video dan Poster Terhadap Pengetahuan dan Sikap Anak Dalam Pencegahan Penyakit Diare. Jurnal Kesmas Asclepius (JKA), 1(1), 76-85.

Kementerian Kesehatan RI. (2016). Situasi Lanjut Usia (Lansia) di Indonesia. In Kementerian Kesehatan RI.

Kementerian Kesehatan RI. (2019). Laporan Riskesdas 2018.

Kusnanto. (2019). Hubungan Tingkat Pengetahuan dan Diabetes Self Management dengan Tingkat Stress Pasien Diabetes Mellitus yang Menjalani Diet. Jurnal Keperawatan Indonesia, 22(1), 31-42.

Machfoedz, M. (2010). Komunikasi Pemasaran Modern. Cakra Ilmu.

Notoatmodjo, S. (2010). Ilmu Perilaku Kesehatan. PT. Rineka Cipta.

Notoatmodjo, S. (2012). Promosi Kesehatan Dan Perilaku Kesehatan. PT Renika Cipta.

Sartika, E. (2017). Hubungan Tingkat Pengetahuan Tentang Diet Dengan Kepatuhan Diet Penderita Hipertensi di Puskesmas Padang Bulan. Jurnal Sains Dan Teknologi Farmasi, 19(1).

Sofiana, L., Puratmadja, Y., Kartika, B, Q, S., Pangulu, A, H, R., \& Putri, I, K. (2018). Upaya Peningkatan Pengetahuan Tentang Hipertensi Melalui Metode Penyuluhan. Jurnal Pemberdayaan: Hasil Pengabdian Kepada Masyarakat, 2(1), 171-176.

Sumartono, \& Astuti, H. (2018). Penggunaan Poster Sebagai Media Komunikasi Kesehatan. Komunikologi, 15(1), 8-14.

Undang-Undang Kesehatan No. 23. (n.d.).

WHO. (2011). Hypertension Fact Sheet. South-EastAsia: Departement of Sustainable Development and Healthy Environments. Geneva. In World Health Organization.

World Health Organization, (Who). (2019). Hypertension. WHO.

Wowiling, C., Goenawi, L. R., \& Citraningtyas. (2013). Pengaruh Penyuluhan Penggunaan Antibiotika Terhadap Tingkat Pengetahuan Masyarakat Di Kota Manado. Jurnal Pharmacon, 2(3), 24-28. 